\title{
STATE AND CIVIL SOCIETY: G.W.F. HEGEL CONCEPTION ON THE STATE'S CONSTITUTION
}

\author{
Linda Sudiono*
}

Administrative Law Department, Faculty of Law Universitas Atma Jaya Yogyakarta

Jl. Mrican Baru Nomor 28, Caturtunggal, Depok, Sleman, D.I. Yogyakarta, 55282

\begin{abstract}
This study aims to discuss the relationship between State and Civil Society according to G.W.F. Hegel and its implications towards the formation of State and Law. This study is expected to result critiques of Hegel's state and civil society conception as this conception has been implemented in Indonesia through Integralistic concept. The method of this study is normative study with discourse analysis through critical approach. The result shows Hegel's view of the relationship between Civil Society and State (including its Constitutional Laws) focuses on the dialectical interaction between the particularity of Civil Society and the universality of State.
\end{abstract}

Keywords: state, civil society, constitution.

\section{Intisari}

Tujuan dari penelitian ini adalah untuk mendiskusikan tentang hubungan antara Negara dan Masyarakat Sipil menurut G.W.F. Hegel dan implikasinya terhadap pembentukan Negara dan Hukum. Studi ini diharapkan menghasilkan kritik terhadap konsepsi negara dan masyarakat menurut Hegel, yang pernah diterapkan di Indonesia melalui konsep Integralist. Metode penelitian ini adalah penelitian normatif dengan analisis wacana melalui pendekatan kritis. Hasilnya menunjukkan pandangan Hegel tentang hubungan antara Masyarakat Sipil dan Negara (termasuk Hukum Konstitusionalnya) berfokus pada interaksi dialektis antara kekhususan Masyarakat Sipil dan universalitas Negara.

Kata Kunci: negara, masyarakat sipil, konstitusi.

\section{Pokok Muatan}

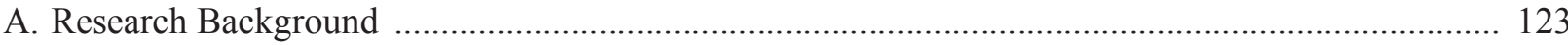

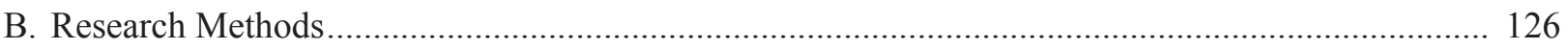

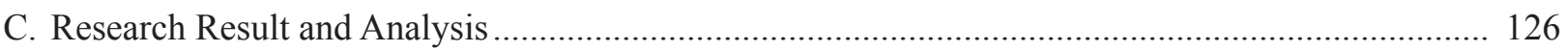

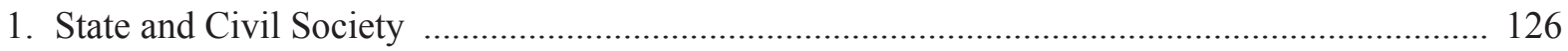

2. The Implications of Hegel's Conception of the State and Civil Society and the Relationship

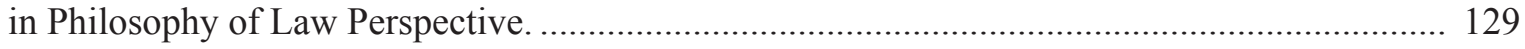

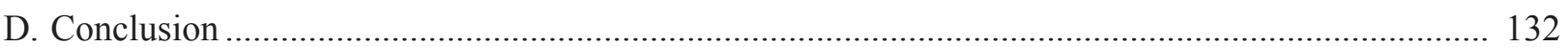

Correspondent address : lindaSD@uajy.ac.id. 


\section{A. Research Background}

Georg Wilhelm Friedrich Hegel, well known as G.W.F. Hegel or Hegel (1770- 1831) was one of the most important German philosophers. His knowledge was encyclopedic, his insight was far-ranging. He was nicknamed as "the modern Aristotle." His influence was also very wide, particularly after his death. Karl Marx, one of the sharpest critics of Hegel, was also influenced by him. Hegel's Idealism did not prevent the father of Scientific Socialism to accept Hegel's dialectical method in order to build his own materialist conception of history. In the words of the great Russian revolutionist V.I. Lenin, according to Marx, dialectics is "the science of the general laws of motion, both of the external world and of human thought."'In Lenin's observation, Hegel's philosophy was adopted by Marx in order to establish a revolutionary theory and science. The revolutionary aspect of it as so-called Dialectics, had further developed by Marx by linking it to historical material subject by researching the origin and the establishment of knowledge. ${ }^{2}$

One of the prominent topics in Hegel's philosophy is the relationship between State and Civil Society. Hegel discussed these topics especially in his works, Philosophy of Right, which was published for the first time in $1821 .{ }^{3}$ Philosophy of Right is first and notably political philosophy which verifies the progressive levels of human interests in institution ${ }^{4}$. In this publication, Hegel focused on analyzing the "ethical universe" which represented by the modern state. The modern state is a manifestation of concrete liberty in which the particular interests of civil society are reconciled. Civil society as a concept is considered as a field positioned between the state and the family. The concept of civil society is juxtaposed with the state of nature as a realm apart from politics and economics. This is the realm in which solidarity of free associations of individuals have a role to complement the state's power. Besides it, civil society is also described as social structure that function is headed to more or less democratic or authoritarian ends. ${ }^{5}$ Therefore, it is pivotal to observe the internal dynamic of civil society. This is due to the assimilation of contradiction in civil society that will be completed in the State as "the actuality of concrete freedom". ${ }^{6}$

In the Introduction to his Philosophy of Right, Hegel explains the concept of his philosophical project along with the concepts of will, freedom, and right. Hegel asserts the philosophic science of rights have as its object the idea of right. ${ }^{7}$ What he meant by the idea of right are the conception of right and the realization of the conception. ${ }^{8}$ According to

V.I. Lenin, 1964, The Three Sources and Three Component Parts of Marxism, New Age Publisher, Australia, p. 13.

Ibid.

The orginal title of this Hegel's work is Naturrecht und Staatswissenschaften in Grundrisse; Grundlinien der Philosophie des Rechts (Natural Law and Science of the State; Elements of Philosophy of Right). This works was republished by Eduard Gansin 1833 and 1854 as a part of Werke, Vol. viii, which included additions form notes which were made by Hegel's students. Translation in English, which was prepared by T. M. Knox, referred to editions of 1833 and 1854, as well as editions which was published in 1923 by Georg Lasson, which included corrections of previous editions. In English, this book is well known as Philosophy of Right.

Paul Edward, "Positive Law in Hegel's Philosophy of Right", Sigma: Journal of Political and International Studies, Vol. 5, No. 3, January 1987, p. 26.

Anuradha Mundkur and Laura J. Shepherd, "Civil Society Participation in Women, Peace and Security Governance Insights from Australia", Security Challenges, Vol. 14, No. 2, Special Issue : Celebrating and Interrogating Women and National Security, 2018, p. 86-87.

" Hegel's conception of freedom was inspired by the historical events of the French Revolution from which Hegel

formulated the view of human ratios and consciousness. The consquences of French Revolution impacted on individual and social freedom that did not arise in Germany, which had to deal with the State authorities. The concept of freedom has the meaning of success in changing the monarchy system into a state system that is supported by the concepts of liberte, egalite, fraternite, a system that is free from absolutism. On the other hand, Hegel readings to Kant and Descartes additionally contributed to the emergence of Hegel's work entitled Phenomenology of Spirit. The principle of Hegel's philosophy in this work is individual subjectivity. According to Hegel individual subjectivity is active and creative, who have the ability to assert themselves with regards to the pressure. This ability will generate the self-consciousness of subject. The emergence of self-consciousness will form the knowledge. Resultly, the freedom is emanated by the subject to confront against all forms of oppression. See also Chris Arthur, "Hegel and The French Revolution", Radical Philosophy, Issue 52, Series 1, Summer 1989, p. 8-9 and Larry Krasnoff, 2008, Hegel's Phenomenology of Spirit, Cambridge University Press, Cambridge, pp. 63-66.

Hegel, 1952, Philosophy of Right, Clarendon Press, UK, p. 13.

Ibid. 
Hegel, his philosophical approach to the Idea of right (Recht) probed into the inner meaning and necessary determinations of law or right. He insists that free will was the basis and origin of rights. Idea, Mind, or Spirit (Geist) generally objectified itself in a system of rights (human social and political institutions). The system give expression to freedom, which is viewed by Hegel as the substance and the goal of rights. ${ }^{9}$

Hegel structures his Philosophy of Right in to what he called as the stages in the development of "the Idea of the absolutely free will." 10 As his predecessor Kant, Hegel believe rationality is the way to achieve the real freedom. According to Kant, a moral act must be based on the universal reason and it must be selected by free, rational, and autonomous choice. It results the idea of rational neutrality of moral reason. Furthermore, the notion develops into a distinction between conscience and the good, between necessary as well as universal good beings and a contingent and specialty of conscience. For Hegel there is a gap in Kant's theory of moral reasoning. Filling this gap is crucial to ensure that humans are to be moral consistently. Hegel develops a concept of Sittlichkeit (Ethical Life) by uniting the universality of ethical social life and particularity which contained specific elements of moral action. Thus moral action is determined by the attitude imposed by society and institutions upon us. He resists the distinction of the 'trustful conviction to what is publicly accepted as true' and the idea of freedom which deviates from approved public opinion. This distinction is to divide individual subjects from themselves. On the other words, modern social institutions such as family, civil society, and the State provides rationality that offers a pace to pursue ultimate freedom. ${ }^{11}$

The accomplishment of Sittlichkeit (ethical life) is the reconciliation of the state's constitution. Therefore, it is the final stage which is the synthesis of legal right and individual morality ${ }^{12}$. It occurs through the objectification of the will in the institutions of the Family, Civil Society, and the State. ${ }^{13}$ Hegel holds the conception that all human beings are intrinsically free, but individuals are not always realize this. Human's consciousness depends on what is the thought of the society around them and unaware of their freedom. Consciousness differentiate itself from its intentional object. However at the same time, the intentional object is awareness based on experiences. The experiential and the intentional elements of consciousness are both required on Hegel's account. ${ }^{14}$ This is why individual freedom develops together with the shared consciousness as the part of society member and manifests in their practices and institutions. ${ }^{15}$

Hegel passes from the abstractly individualistic frame of Abstract Right to the social determinacies of Sittlichkeit or Ethical Life. It is analyzed by considerations first of wrong, the negation of right, and the punishment that such wrong entails the negation of wrong. Therefore, the "negation of the negation" of the original right ( $\S 97-104)$, and then of morality, conceive more or less as an internalization of the external legal relations presupposed by punishment. For instance, the state has an intention to notify its members about the recognition of the right per se, which is essential to organize social life, by using punishment in the criminal. ${ }^{16}$

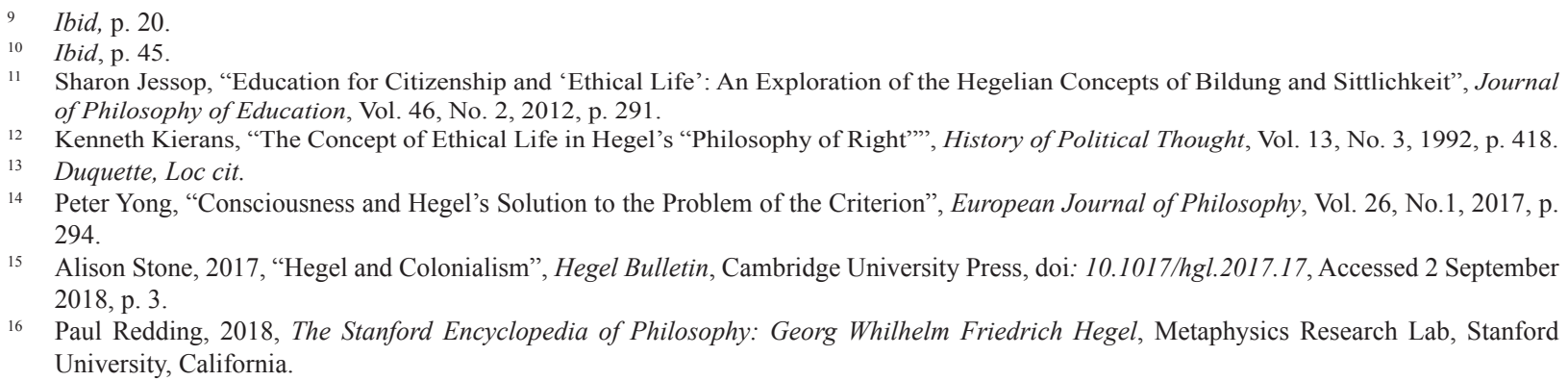


It is clear that in his triadic system, Hegel put Civil Society between Family and State. ${ }^{17}$ According to Hegel, these three institutions were dialectical moments of Ethical Life. We know that the Ethical Life itself was a synthesis of the idea of objective good (Abstract Right) and the subjectivity of human will (individual Morality). This synthesis presupposed that human freedom is "not just an attitude of inward autonomy, but a whole social framework [in] which the human being realized her or himself. ${ }^{18} \mathrm{On}$ the other words, human freedom would manifest outwardly in the modern system of law (laws, norms), and inwardly in the depth of the consciousness of all society members. It would come to its perfection through Moral-Social Order (Family, Civil Society, and State). ${ }^{19}$ In this context, Family is the thesis, Civil Society is its antithesis, and State is the synthesis of them.

As an antithesis, in certain sense, Civil Society is an ethical moment that is more advanced than Family. In the independence and individual consciousness, human freedom is realized more than only dependence on collectivity and lack of individual consciousness. This antithesis, however, has certain problem. The problem is the placing of human beings in an arena which makes them to see their fellows as their competitors even the means in order to pursue and achieve their own interests. According to Hegel, this antithesis needs to be overcome. The end is not to set aside the progress it has achieved, that is the independence and individual consciousness, which is constructive to the society as a whole. The end is to bring that progress into the higher level. For Hegel, this higher level, as a synthesis of Civil Society and Family, is the State.

Consequently, individuals are merely tools or means to achieve their own particular goals. ${ }^{20}$ Paradoxically, these particular goals imply universality. These goals are to be attained through an effort which is simultaneous to the other's welfare. ${ }^{21}$ It means that fundamentally particularities are necessarily conditioned by universality. Therefore, The Civil Society is a mediation area. Civil Society mediates particular wills through social interactions. By that way, Civil Society is means to educate individuals to achieve a higher consciousness, namely universal consciousness. It assures "free play for every idiosyncrasy, every talent, every accident of birth and fortune, and where waves of every passion gush forth, regulated only by reason glinting through them."22 This universality is truly manifested in the State, which expresses rationality and facilitates the individuals' freedom in the Constitution. The concern is this concept puts positive law, as well as constitution, as the final form. Moreover, the state functionaries as well as law enforcer are posed as the people used by the Absolute Idea to manage Civil Society. It may lead to the deviation of mandate entrusted by the people.

The other issue is the concept of the State

17 According to Hegel, Family is characterized by love. For him, love is feeling of Mind about its unity. One is conscious of her or his individulaity in this unity, not as individuals, but as a member which is essentially connected to other members in the family. On the basis of this, Hegel sees that familial love implies a contradiction between unwillingness to become an independent person, and the will to be acknowledged by other persons. Accordiing to Hegel, familial love is a unity which is real and ethical. Because it is a subjective feeling, however, familial love is limited in mantaining the unity. In the Family, ethical idea is still in the form of concept. Consciousness of wholeness or totality is prominent. On the other side, in Civil Society there has been particularity with its determination. Accomplishment of subjective needs has a prominent place. The pursue of private goals and the self-centerdeness lead to free social activity and economy. The State gives synthesis between principles which regulate the Family, and principles which regulate Civil Society. Rationality of the State consists in realization of substantial will which is universal in the consciousness of particular individuals which is elevated to consciousness of the universal. Therefore, it is in the State that freedom becomes explicit and objecitve. See Hegel, Op. cit., p. 160, 161, 178-180, 230.

18 Franz Magnis-Suseno, 1992, Filsafat Sebagai Ilmu Kritis: Hegel tentang Moralitas dan Struktur Sosial, Kanisius, Yogyakarta, p. 107.

9 Ibid.

Ibid.

21 Universality is implied in the differentiation in particular needs as far as the welfare of the individuals is intrincally and closely connected to the welfare of other individuals. According to Hegel, it is because each individuals are required to be involved actively in the mutual acitivities such as commerce and trade. This system of mutual dependence is not self-conscious. Instead, it exists only in abstraction of individual effort in order to satisfy her or his needs. Hegel, Op. cit., p. 179.

22 Ibid. 
as an embodiment of the holy soul. State is viewed as the institution to unite all elements in a complete and move towards the final goal. It might indicates the existence of absolutism of state power. Consequently, this concept developed as an argument for the emergence of totalitarianism of the state.

On the basis of the background stated above, this article discusses the relationship between State and civil society according to G.W.F. Hegel, particularly in sections $\$ 260-271$ of his Philosophy of Right. Furthermore, this article also expounds the implications of G.W.F. Hegel's view of State and Civil Society towards the formation of State and Law.

This study is expected to result criticism of Hegel's state and civil society conception. this concept was adopted by the integralistic concept that implemented by New Order Era. In-depth analysis of this study is expected to avoid a similar concept that inspire the authoritarian practices to re-emerge in the Indonesian government system.

\section{B. Research Methods}

This study is normative study which is done to collect secondary data, including primary, secondary, and tertiary legal materials including books, journals, etc. the materials are related to civil society and State according to Hegel's conception. The research analysis approach is discourse analysis which focus on higher-level organizational properties of dialogue or of written texts. The type of discourse analysis used is critical approach that attempt to combine a social theory of discourse with a method of text analysis. ${ }^{23}$

\section{Research Result and Analysis \\ 1. State and Civil Society}

In sections \$260-271 of Philosophy of Right, Hegel discusses the relationship between State and Civil Society. According to Hegel, State is the actuality of concrete freedom. The concrete freedom itself presupposes that individuals do not only achieve their complete development and gain explicit recognition for their right. ${ }^{24}$ Instead, in the one side those individuals ought to "pass over of their own accord into the interest of the universal", 25 and in the other side they oughtto "know and will the universal." ${ }^{26}$ Furthermore, the individuals ought to be conscious of the Universal as their own substantive Mind or Idea. They ought to make the Universal to be their own ends and aspirations, and pursue them actively. ${ }^{27}$

In relation to Family and Civil Society, according to Hegel the State is an external necessity and has an authority over family and civil society. ${ }^{28}$ Therefore, the laws of the interests of Family and Civil Society depend on the State and ought to submit to it. ${ }^{29}$ On the other side, for Hegel, the State is the goal which is immanent in Family and Civil Society. ${ }^{30}$ It means that the State is the accomplishment of the essential goals of Family and Civil Society. It imply that the power of the State consists of the unity between its universal goal, aspiration and the particular interests of individuals in Civil Society. ${ }^{31}$ Concretely, the unity consists of the fact that individuals have duties to the state in proportion as they have rights against it. ${ }^{32}$

According to Hegel, the State does not know separation between duty and rights. Duty and rights are one in the whole. He argues that in the State,

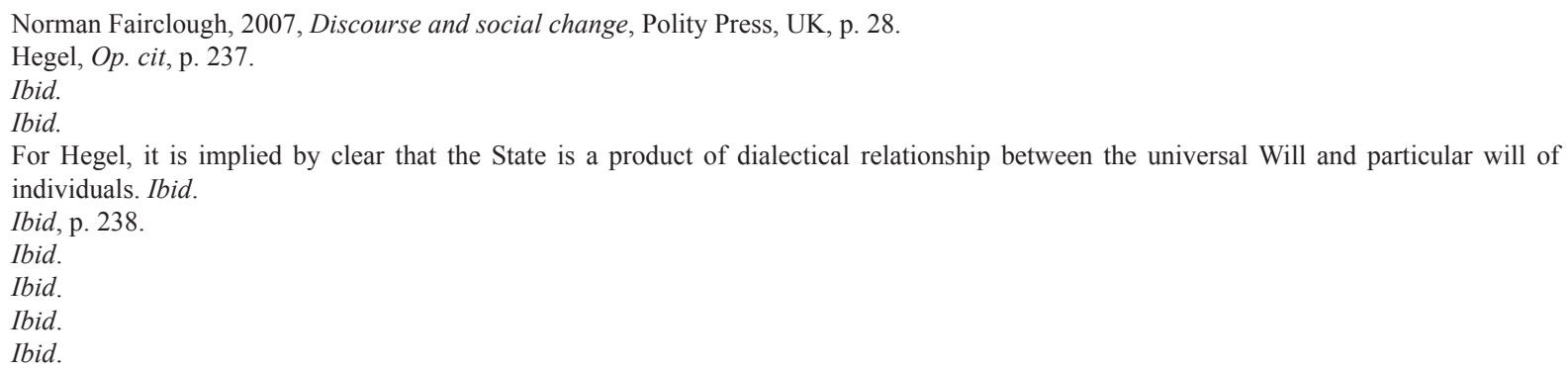


"as something ethical, as the inter-penetration of the substantive and the particular, my obligation to what is substantive is at the same time the embodiment of my particular freedom." This means that in the state, duty and right are united in one and in the same relation. ${ }^{33}$ Hegel insists that individuals seek to receive their own rights, so their particular interests are unified to the universal interests. Hegel rejects the view that particular interests ought to be submitted to the universal interests. Particular interests should be place in coherent with the universal, therefore both the particular interests and the universal are sustained. ${ }^{34}$

Hegel sees a harmony between the Universal and the Particulars as the aspects of identity and of difference in the relationship between Civil Society and State. The aspect of identity emerges in the acknowledgment given by individuals to the ethical laws. It asserts they do not live as private persons for their own goals, but in the very act of willing, they will be in the light of the universal, and their activity is consciously aimed at none but the universal. ${ }^{35}$

The aspect of difference is found in its [modern state, author] particular members and with private well-being. ${ }^{36}$ It means the right of subjective will is defended in Civil Society. Therefore, according to Hegel, the universal must be furthered, but subjectivity on the other hand must attain its full and living development. As both these moments subsist in their strength, the state can be regarded as articulated and genuinely organized. ${ }^{37}$

Hegel states that Mind or Idea divides itself into Family and Civil Society. Family and Civil Society are the two ideal spheres of its concept of the Idea. ${ }^{38}$ Even though these two areas represent limited modes, according to Hegel the Idea does so only in order to rise above its ideality and realize infinite actual mind explicitly. ${ }^{39}$ By that way, the Idea assigns the material of this its finite actuality, viz. human beings as a mass. ${ }^{40}$ Concretely, it means the function assigned to individuals is visibly mediated by their circumstances, caprice and personal choices about the position in life. ${ }^{41}$ In Family and Civil Society, the Particular and individuals have their immediate and reflected reality. ${ }^{42}$ Meanwhile, Mind or Idea presents as their objective universality "glimmering in them as the power of reason in necessity." ${ }^{43}$

According to Hegel, individuals are producing two extremes. At the first extreme is the explicit individuality of consciousness and will. At the other extreme is the universality that knows and will which is the substantive. ${ }^{44}$ At these two extremes, individuals would achieve their rights as far as their own private personality and substantive basis are actualized. ${ }^{45}$ As Hegel explains they acquire their right in the family of these respects directly and in the civil society indirectly. Regarding to this, social institutions provide the "substantive of self-consciousness" that contains the universal in their particular interests implicitly. ${ }^{46}$

Those social institutions are the components of Constitution in the area of particularity. Hegel states the Constitution as rationality that is advanced and actualized. ${ }^{47}$ Rationality itself is concrete both

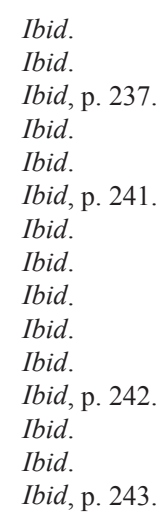


in its content and in its form. The rationality is concrete in its content when it realized the unity of the objective freedom (freedom which was universal or substantial will) and the subjective freedom (freedom of individuals in knowing and willing their own particular goals). The Rationality has a concrete form in the action of self-determination or the laws or the principles which manifests universal thoughts.

Having been considered as components of a rational Constitution, those institutions will be the firm foundations for the State. ${ }^{48}$ Furthermore, those institutions are also the foundations which are solid to the belief of individuals on the State and their positive sentiments toward it. ${ }^{49}$ Therefore, those social institutions are the pillars of public freedom..$^{50}$ As explained by Hegel, in those social institutions the particular freedom is realized, and therefore there is implicitly presence and even unifies freedom and necessity. ${ }^{51}$

Ontologically, this conception can be articulated as following: 1) the Mind or Idea develops in dialectical way as subjective substantiality and objective substantiality; 2) Subjective substantiality consists in the character of individuals, while 3 ) objective substantiality is found in the organism of the State. ${ }^{52}$ Regarding to this Hegel states that this necessity in ideality is the inner self-development of the Idea. It means ${ }^{53}$

"As the substance of the individual subject, it is his political sentiment [patriotism]; in distinction therefrom, as the substance of the objective world, it is the organism of the state, i.e. it is the strictly political state and its constitution."

The explanation presented above shows clearly that Hegel views the State as an organism. This is reflected in his following statement: ${ }^{54}$

"These different sides of the state are its various powers with their functions and spheres of action, by means of which the universal continually engenders itself in a necessary way; in this process it maintains its identity since it is presupposed even in its own production."

In this context, Constitution is a concrete embodiment of the expressing organism, the State. Hegel argues the Constitution is something produced perpetually by the state, while it was through it that the state maintained itself. ${ }^{55}$ The significance of the Constitution for the State can be seen in Hegel statement that if the state and its constitution fell apart, or if the various members of the organism freed themselves, the unity produced by the constitution was no longer an accomplished fact. ${ }^{56}$ According to Hegel, this is assumed "with the fable about the belly and the other members". ${ }^{57}$ Hegel insists, ${ }^{58}$

"The nature of an organism was such that unless each of its parts is brought into identity with the others, unless each of them is prevented from achieving autonomy, the whole must perish. By listing attributes, axioms, \&c., no progress can be made in assessing the nature of the state; it must be apprehended as an organism."

The dialectical way of reasoning is very important to understand Hegel's view of Civil Society and the State as well as its constitution. It is also pivotal to figure out the relationship between civil society and the State. Civil Society focusses on the particular. State focusses on the Universal. The Constitution, including modern laws derived from

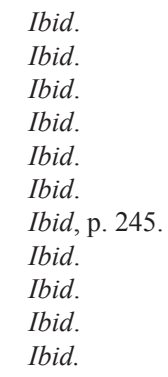


it, accommodates the Particular and provides the place in the Universal. The Constitution is not the purpose of the inclination, caprice and the sentiment. Nor The Constitution is appropriate with tyranny and force to meet man's needs because they are not section of the decent concept of law. It serves an educative function by instructing individuals how to organize themselves within society. The purpose of law is to create the well being and blissfulness of individuals by actualizing their subjective freedom. ${ }^{59}$ In other words, The Constitution facilitates the Universal to lead the particular to their accomplishment. The Constitution connects the particular freedom and the common interests to the Universal. It is occurred by giving rational meaning both to the particular freedom and to the common interests. In the other words, Hegel's view about the relationship between Civil Society and State (including its Constitutionand Laws) focus on the dialectical interaction between the particularity of Civil Society and the universality of State.

2. The Implications of Hegel's Conception of the State and Civil Society and the Relationship in Philosophy of Law Perspective.

Hegel's principal discussion of law can be found in his establishment of civil society. Nonetheless, the existence of a legal system is included in his idea of the state. The main function of the law for Hegel is to protect individual life and property ${ }^{60}$. The law objective must be consist of applicable general norms of the state to be applied in specific cases. The quintessence of law is not only described by referring to its general character. If generality is a legal form that is required, the problem is completely particular type composition. This is the motive of individual interests, generally structured which serves as the basis for the legal expression of the civil, that which Hegel calls the Not-und Verstandesstaat. In its objectivity, the law is a structure that allows individuals to maximize the satisfaction of their desires by being able to transcend their own subjectivity. ${ }^{61}$

In philosophy of law, Hegel has tried to make an encounter even reconciliation between the particular interest of individuals in Civil Society and the interest of all society members as a whole. The encounter and reconciliation are administered by the State. Hegel's effort is both very interesting and very significant. It is clear that in Hegel's view, the State, through Constitution it has decreed, is realizing the true human freedom. ${ }^{6}$ The freedom, which is meant, is a freedom which is rational. It refers to the using of human free will in a rational way, namely in accordance with the Objective Idea which embodies itself in law, morality, and SocialMoral Order. Hegel firmly rejected dualism of Mind and Will. The Will is based on Instinct, not on Free Will. He views that only Free Will is the real Will. Free Will, that is rational Will, is reflected in the institutions in which it projects itself. ${ }^{63}$

In the harmony between the Particulars and the Universal, the real freedom would be accomplished. However, in the perspective of the philosophy of law, Hegel's concept of Civil Society and State (including its Law or Constitution) and their relationship have some serious implications. By positioning the State vis-à-vis the Civil Society or the Universal vis-à-vis the Particulars, Hegel has put the State on the level that is above society. The State is the manifestation of something which is ideal and universal. By obeying the State, individuals, as citizen, are being freed from their narrow-mindedness which only makes an effort for their narrow interests. ${ }^{64}$

On the one hand the State is seen as the unity

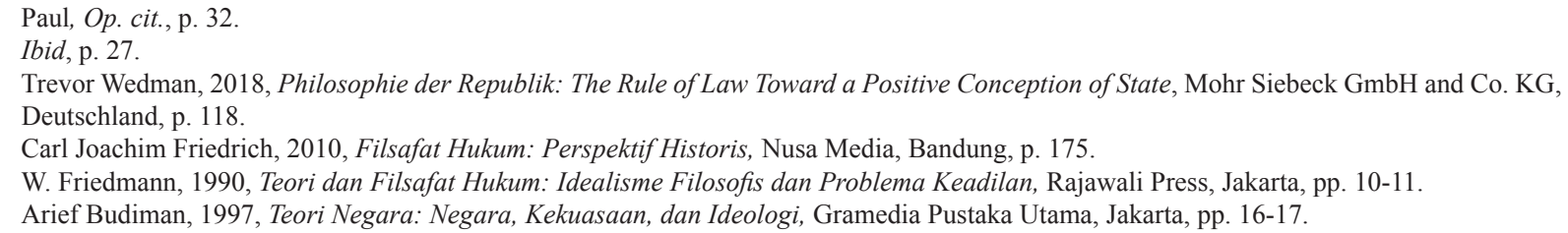


of the objective interest. On the other hand (and at the same time) Civil Society is viewed as an arena of subjective interests competition or an arena of particularities which exist in mutual competitions and conflicts. This contradiction implies several things as follow:

First, State is regarded as both an arbiter and all-wise manager of the particular interests which are competing to each other. It is clear that the State has a rationality which is higher than Civil Society. The State is more rational than Civil Society. The State also has a power which is very strong to enable it to play its role on Civil Society. In this connection, therefore, the challenges arise. At stake is the function of criticism of the State, which is precisely expected to come from the Civil Society. It is also implied that democracy would become irrelevant. The State is the entity which is most rational and most powerful. Therefore, criticism and democracy would not be needed. In this context, Hegel's political idealism has fundamentally antidemocratic character. ${ }^{65}$ Sovereignty is represented and determined by the State as metaphysical organism, despite the people. ${ }^{66}$

Second, the Constitution is made to accommodate the particular freedom and to place it in the universal interest. In its implementation, however, this view can be easily deteriorated into an overestimation of the positive law. At the same time, it may cause an underestimation of the other forms of the law (for instance customary law). Logically, therefore, a conformity to the positive law is final. ${ }^{67}$ This view can also be degenerated into a treatment which denies individual aspirations and the sense of justice which lives in the midst of Civil Society. In this context, the positive law would be used as a pretext for those who have power to do injustice and arbitrariness. In fact, both theoretically and practically, the positive law, including Constitution, is open to be interpreted in such away that comforms to the perspectives of those who have certain interests.

Third, let us assume that Hegel's conception of the State and the Constitution are noble. we must be aware that the State is managed by personalities who they themselves originate from Civil Society. The constitution is also produced and enforced by people who come from the same sphere. It is very dangerous if we assume that they are thoroughly free from "defects" suffered by Civil Society which is their origin. Hegel's view clearly assumes the State functionaries, the law makers, and the law enforcers in the same manner of Plato's ideal of philosopher-king type of the ruling elite.

For Plato, only the philosopher-kings, namely people who have wisdom (sophia) which is superior on the basis of their knowledge about the ideal forms (eidos), who are rightful to manage society in the polis. ${ }^{68}$ Those philosopher-kings, according to Plato, have both excellent ability and high integrity to carry on the noble task of managing society. They are alike super humans which are extraordinary in their insights and skills to serve the State and enforce the Laws. They are also, if we use a Javanese proverb, sepi ing pamrih rame ing gawe (working hard unselfishly).

In the same way, according to Hegel, the functionaries of the State and the law servants are the people used by the Absolute Idea to manage Civil Society. However, this concept emerges some crucial problems. The functionaries might be entrusted the mandate to serve the state and enforce its constitution. Nevertheless, it is wise for us to reflect on the warning given by Karl Marx. There is always an open possibility for those people to deviate from the mandate which has been entrusted

\footnotetext{
65 Henry J. Schmandt, 2015, Filsafat Politik: Kajian Historis dari Zaman Yunani Kuno sampai Zaman Modern, Pustaka Pelajar, Yogyakarta, p. 498.

66 Ibid.

67 Theo Huijbers, 1990, Filsafat Hukum dalam Lintasan Sejarah, Kanisius, Yogyakarta, p. 110. Huijbers says, “... all laws, including laws of the family and the society, could only be a valid law in framework of the State ... The implication for law is that the law which prevails is the law coming from the State, namely the positive law.."

68 Ibid, p. 23.
} 
to them. ${ }^{69}$ Criticizing bourgeois state praised by Hegel, for Marx, the idea that the common interests of the society as a whole, are being realized in the bourgeois State, is a fiction. The "bureaucrats," the way Marx referred to the State and Law functionaries, often use the State power to pursuit their own interests. Karl Marx argues that for the individual bureaucrats, the purpose of the state becomes his private purpose, a hunt for promotion, careerism. ${ }^{70}$ In reality, there are many cases which show that people who bear the mandate to manage the State and administer the Constitution have used the State and its Constitution to serve the intentions and goals which precisely harm the sense of justice in the midst the Civil Society.

Fourth, Hegel's view of State and Law is susceptible to degenerate into authoritarianism even totalitarianism. By giving an attribute to the State and its Constitution as noble institutions, one may view the State and its Constitution as the best entities, otherwise, at the same time consider the civil society as the worst.

This dichotomy may lead to a reasoning which argues for the need of the presence of a strong State in order to establish "law and order" among the Civil Society which has always the tendency to chaotic. In one or another way, it means there is the expectation for the coming back of the State either in the figure of Leviathan as proposed by Thomas Hobbes, or the Bonapartist. These state figures claim to be the real representative of the people par excellence who will act according to the interest of all the people and on their behalf. This real representative is applied in order to enforce the Law and run the State with the greatest power.

The concept of the State as an embodiment of the holy soul ${ }^{71}$ indicates the existence of absolutism of the state power. This concept had inspired Soepomo thoughts of integralistic State. Soepomo delivered this concept at the Session of the Indonesian Independence Preparatory Agency (BPUPKI) on the formulation of Indonesia constitution on May 31, 1945. This government system concept considered contains eastern cultural value since it bases on the unity of leadership and people into the principle of organic unity of the country. ${ }^{72}$

After the New Order overthrown by mass movement, a polemic emerged over the Soepomo concept of integralistic state which was seen as having implications for the establishment of Soeharto military totalitarian state. Integralistic state is one of the theories that was born by Soepomo's thought about "the unity of organic society" which prioritizes "the interests of the whole not the interests of individuals" which many refer to the teachings of Hegel. ${ }^{73}$ In the concept of integralistic State, the state is a unified society that is integrally structured. Society is an organic unit that is not separate, however, moves together into an ultimate and essential goal. In the process of finding this ultimate goal, the leader acts as the head who will guide the movement of other organic elements, so as to create harmony between the leader and the people. The threat of imbalance in the organic structure must be resolved by means created by the state. This aim is not to impede the "sacred" journey of the community in realizing shared interests. All elements of society are a unified of the whole, where the separation from one element will threaten the balance of harmony in life. Consequently, this concept developed as an argument for the emergence of authoritarianism of the state.

Fifth, Hegel views of Civil Society and State (and its Constitution/Laws) do not give any place

\footnotetext{
Karl Marx, 1975, Karl Marx Early Writings: Critique of Hegel's Doctrine of State, trans. Rodney Livingstone and Gregor Benton, Vintage, New York, pp. 193-194.

Ibid, p. 108.

The state represents the holy soul to unite all elements in a complete move towards the final goal. Ibid.

Otto Gusti Madung, "Paradigma Holisme Hegelian and Kritik atas Liberalisme”, Jurnal Ilmiah Peuradeun, Vol. 2, No. 2, May 2014, pp. 4647.

73 Marsillam Simanjuntak, 1994, Pandangan Negara Integralistik, Sumber, Unsur dan Riwayatnya dalam Persiapan UUD 1945, Pustaka Utama Grafiti, Jakarta.
} 
to class antagonism. It is clear that Hegel see Civil Society as an arena of competition of the particular interests. Those particular interests, however, are simply assumed as things which are inherent in every members of Civil Society. It is as if, borrowing Marxist terminology, that all members of Civil Society are bourgeois.

Civil Society itself consists of antagonistic classes. These classes have their own fundamental interests which are opposed to each other. Bourgeois class is the class of the owner of the means of (mass) production. They are living from extracting Surplus Value produced by the working class. The working class have no the means of production. They are living by selling their ability to work to the bourgeouis. In turn the bourgeoisie exploits them through the extraction of Surplus Value.

In the context of class antagonism in Civil Society, we may imagine the nature of the State and its Constitution/Laws which are decreed by the State. If the bourgeois class is the ruling class in the Civil Society, it is easy for us to understand the State as an institutionalization and a political consolidation of the political-economy power of bourgeoisie in order to secure capitalist relations of production. By this given fact, State and Constitution/Laws are essentially serving or facilitating the interests of bourgeoisie in Civil Society. ${ }^{74}$ Logically, it means that both structurally and instrumentally State and its Constitution are the bourgeois State and Constitution. By not giving place to the class antagonism or at least neglecting it, in unintentional way Hegel's view of the relationship between State and Civil Society has played ideogical role : It is making an illusion on the working class and other layers of the oppressed working people. The illusion is that the working people may have a State which is always ready to make serious efforts to enforce justice in order to defend them in the face of the capitalists or bourgeoisie.

\section{Conclusion}

Hegel's concept of Civil Society and the State, including its Constitution and their relationship, has associated Civil Society with particular interests in the one side, and has associated State with universal interests in the other side. Civil Society is an arena to pursue private interests of individuals who have become its members. State does not annul those interests, but place them in the context of wider interest, namely the universal interests, which is nothing more than the common interest or the interest of society as a whole. Through rational Constitution which is decreed by the State, the Particulars and the Universal are reconciled and made harmonious. By this way Hegel resolved the antithesis between the particular interests and the Universal interest.

However, Hegel's concept has raised some serious problems in connection to the nature of State and of the Constitution, democracy and human rights. First, State is both an arbiter and allwise manager of the particular interests which are competing to each other. It is clear that the State has a rationality which is higher than Civil Society. The State has a power which is very strong to enable itu to play its role on Civil Society. In this connection, what is at stake is the function of criticism toward the State, which is precisely expected to come from the Civil Society, therefore democracy would become irrelevant. Second, the Constitution is made to accommodate the particular freedom and to place it in the universal interest. This view can be easily deteriorated into an overestimation of the positive

\footnotetext{
74 Ernest Mandel, 2006, Tesis-Tesis Pokok Marxisme, Resist Book, Yogyakarta, p. 71-75. Mandel observes the position and functions of the State in the 19th and 20th centuries. Of the function of the 19th century, he says, "It is not difficult to explain to the workers of 19th century that the bourgeois stata is not 'neutral' in the class struggle, borgoeois state is not 'arbiter'between capital and labour. Bourgeois state is not design to defend what is called as 'common interest,' but that it clearly represents a tool to defend capital against the working class" (p. 71-72). Of the position and function of the State in the 20th century (especially in Western Europe), he insists, "During the 20th century is demonstrating convincingly that it is impossible to use bourgeois parlement and a government based on capitalist ownership and bougeois state as a significant way to fight against bougeoisie. Whatever policy which tries to go along with anticapitalist line is quickly faced with dilemma: to surrender to the squeezing of capitalist power, or to destroy the apparatus of bougeois state and replace the relation of capitalist ownership with the collective taking over of the means of production" (pp. 74-75).
} 
law and at the same time an underestimation of the other forms of the law. Third, Hegel's view clearly assumes the State functionaries, the law makers, and the law enforcers in the same manner of Plato's ideal of philosopher-king type of the ruling elite. Fourth, Hegel's view of State and Law is susceptible to degenerate into authoritarianism even totalitarianism. Fifth, Hegel views of Civil Society and State (and its Constitution/Laws) do not give any place to class antagonism.

\section{BIBLIOGRAPHY}

\section{A. Book}

Budiman, Arief, 1997, Teori Negara: Negara, Kekuasaan, dan Ideologi, Gramedia Pustaka Utama, Jakarta.

Fairclough, Norman, 2007, Discourse and social change, Polity Press, UK.

Friedmann, W, 1990, Teori dan Filsafat Hukum: Idealisme Filosofis dan Problema Keadilan, Rajawali Press, Jakarta.

Friedrich, Carl Joachim, 2010, Filsafat Hukum: Perspektif Historis, Nusa Media, Bandung.

Hegel, 1952, Philosophy of Right, Clarendon Press, UK.

Huijbers, Theo, 1990, Filsafat Hukum dalam Lintasan Sejarah, Kanisius, Yogyakarta.

Krasnoff, Larry, 2008, Hegel's Phenomenology of Spirit, Cambridge University Press, Cambridge.

Lenin, V.I., 1964, The Three Sources and Three Component Parts of Marxism, New Age Publisher, Australia.

Mandel, Ernest, 2006, Tesis-Tesis Pokok Marxisme, Resist Book, Yogyakarta.

Marx, Karl, 1975, Karl Marx Early Writings: Critique of Hegel's Doctrine of State, trans. Rodney Livingstone and Gregor Benton, Vintage, New York.

Redding, Paul, 2018, The Stanford Encyclopedia of Philosophy: Georg Whilhelm Friedrich Hegel, Metaphysics Research Lab, Stanford University, California.

Schmandt, Henry J., 2015, Filsafat Politik: Kajian Historis dari Zaman Yunani Kuno sampai Zaman Modern, Pustaka Pelajar, Yogyakarta.
Suseno, Franz Magnis, 1992, Filsafat Sebagai Ilmu Kritis: Hegel tentang Moralitas dan Struktur Sosial, Kanisius, Yogyakarta.

Simanjuntak, Marsillam, 1994, Pandangan Negara Integralistik, Sumber, Unsur dan Riwayatnya dalam Persiapan UUD 1945, Pustaka Utama Grafiti, Jakarta

Wedman, Trevor, 2018, Philosophie der Republik: The Rule of Law Toward a Positive Conception of State, Mohr Siebeck $\mathrm{GmbH}$ and Co. KG, Deutschland.

\section{B. Journal Article}

Arthur, Chris, "Hegel and The French Revolution", Radical Philosophy, Vol. 52, No. 1, Summer 1989.

Edward, Paul, "Positive Law in Hegel's Philosophy of Right", Sigma: Journal of Political and International Studies, Vol. 5, No. 3, January 1987.

Jessop, Sharon, "Education for Citizenship and 'Ethical Life': An Exploration of the Hegelian Concepts of Bildung and Sittlichkeit", Journal of Philosophy of Education, Vol. 46, No. 2, 2012.

Kierans, Kenneth, "The Concept of Ethical Life in Hegel's "Philosophy of Right"”, History of Political Thought, Vol. 13, No. 3, 1992.

Madung, Otto Gusti, "Paradigma Holisme Hegelian and Kritik atas Liberalisme", Jurnal Ilmiah Peuradeun, Vol. 2, No. 2, May 2014.

Mundkur, Anuradha and Laura J. Shepherd, "Civil Society Participation in Women, Peace and Security Governance Insights 
from Australia", Security Challenges, Vol. 14, No. 2, Special Issue: Celebrating and Interrogating Women and National Security, 2018.

Serequeberhan, Tsenay, "The Idea of Colonialism in Hegel's Philosophy of Right", International Philosophical Quaterly, Vol. 29, No. 3, September 1989.
Stone, Alison, 2017, "Hegel and Colonialism", Hegel Bulletin, Cambridge University Press, Doi: 10.1017/hgl.2017.17, Accessed 2 September 2018.

Yong, Peter, "Consciousness and Hegel's Solution to the Problem of the Criterion", European Journal of Philosophy, Vol. 26, No. 1, 2017. 